\title{
Newly Adopted Corporate Governance Mechanism Impact on the Performance of Public Japanese Overseas Acquirers
}

\section{Faisal A*}

Department of Business Administration, Graduate School of International Management, Aoyama Gakuin University, Japan

\begin{abstract}
This Paper investigate the relationships between two of the main corporate governance components namely the Anti-Takeover Provisions (ATPs) as external component and Ownership Concentration as internal component and the short/long term performance of the Nikkei-listed Japanese cross-border acquirers during the last decade specifically from 2004 to the end of 2013. Market based metrics which is cumulative abnormal returns (CARs) were used to represent the short term performance and accounting based metric which is Return of Assets (ROA) were used to represent the long term performance. Based on 222 events, a quantitative method of events, study and regression analysis were employed to reveal the relationships. The study found a negative, weak and statistically not significant relationship between the ATPs and short/long term performance. The study also revealed that the relationship between ownership concentration and short/long term performance is almost negligible. These findings imply that the newly adopted corporate governance mechanism in Japan is still not as effective as in the other developed markets such as USA and might need more time to reap tangible results.
\end{abstract}

Keywords: Anti-Takeover provisions; Cumulative abnormal return; Corporate governance; Ownership structure; Events study; Regression analysis

\section{Introduction}

The burst of Japan's massive financial bubble in 1990 caused the value of stocks, land and other assets to plummet. Japanese banks had financed their asset purchases using them as collateral. Many banks failed due to a combination of the collapse of asset values and their clients' inability to pay back loans. Japanese manufacturers lost their traditional source of financing, bank loans. Shrunken product demand and persistent excess capacity caused deflation, which became endemic in Japan. Japan's traditional bank-centered corporate governance system was blamed for the nation's economic bust. The beginning of $21^{\text {st }}$ century marked a notable period of corporate governance reforms in Japan away from bank-centered governance and toward marketoriented governance. Mutual or cross shareholdings among Japanese firms and financial institutions decreased rapidly, while shareholdings by foreign institutions increased for high-performing Japanese firms. Thus, a major divergence in corporate governance occurred among Japanese firms. Noting the generally robust performance of the economies of the US, Australia, Canada, New Zealand, and the UK, the Japanese government decided to adopt a US (or, more broadly, AngloSaxon) style corporate governance system over the last decade. A range of corporate governance reforms were instituted, aiming to facilitate market based transactions, competition, individual shareholder rights, as well as transparency and information disclosure. The last decade also witnessed another notable phenomenon for Japanese firms which is the dramatic increase of Cross-Border Merger and Acquisitions (M\&As) fueled by several factors like: domestic market decline, high cost of local labor, globalization among others. All these factors are encouraging Japanese companies to consider entering overseas markets. CrossBorder M\&As is becoming an important and strategic tool for Japanese companies to grow. In 2012, the value of Cross-Border M\&As made by Japanese firms hit new high record of USD 94.5 B which accounted for more than $10.5 \%$ of the total Cross-Border M\&As worldwide (calculated from Bloomberg database). To date there is a lack of knowledge about the relationships between corporate governance and the performance of acquiring firms in Japan especially firms going abroad through acquisitions. Therefore, the aim of this paper is to dig into these two remarkable changes happening to Japanese firms in the last decade by investigating the following:

- The relationships between the new external corporate governance system represented by Anti-Takeover Provisions (ATPs) and short/long term performance of overseas acquiring public Japanese firms.

- The relationship between the non-bank-centered ownership concentration representing the new internal corporate governance mechanism and the short/long term performance of overseas acquiring public Japanese firms.

The rest of this study is organized as follows: the first section reviews the ATPs and Ownership Structure literature and their impact on the performance. Section two presents the sample construction and research methodology. Finally, the last section shows the results with the discussions. The paper closes with some concluding comments.

\section{Literature Review}

\section{Anti-takeover provisions (ATPs)}

Ever Since Anti-Takeover Provisions (ATPs) have appeared on the corporate landscape during the hostile takeover market of 1980s, they have been a topic of interest among researchers and practitioners. Designed to limit shareholder rights or empower managers in the event of corporate takeover attempt.

*Corresponding author: Faisal A, Department of Business Administration Graduate School of International Management, Aoyama Gakuin University, Japan, Tel: +81334098111; E-mail: dE214903@aoyama.jp

Received June 06, 2016; Accepted July 04, 2016; Published July 07, 2016

Citation: Faisal A (2016) Newly Adopted Corporate Governance Mechanism Impact on the Performance of Public Japanese Overseas Acquirers. J Glob Econ 4: 200. doi:10.4172/2375-4389.1000200

Copyright: (c) 2016 Faisal A. This is an open-access article distributed under the terms of the Creative Commons Attribution License, which permits unrestricted use, distribution, and reproduction in any medium, provided the original author and source are credited. 
DeAngelo et al., [1] were among the first to argue that ATPs can influence shareholder wealth. In their managerial entrenchment hypothesis, they argue that ATPs serve to protect managerial positions at the expense of shareholders and thus reduce shareholder wealth. According to this hypothesis, ATPs increase the agency conflict that exists between managers and shareholders.

More recent studies focusing on the relation between ATPs and firm performance or shareholder value seem to largely support DeAngelo et al., [1] in their argument that ATPs decrease shareholder value. Gompers et al., [2] look at the influence of ATPs on firm value and shareholder returns. In their study, Gompers et al., (GIM) select 24 governance provisions tracked by the Investor Responsibility Research Center (IRRC) and use these to create an index for the level of shareholder rights by adding one point for every provision that restricts shareholder rights. The provisions in the GIM index have effects other than takeover protection but most of the provisions in the index, such as supermajority voting requirements, poison pills, or classified boards are ATPs.

Using this index GIM find a strong and significant negative relation between firm performance and the number of ATPs. Using Tobin's $\mathrm{Q}$ as a measure of firm value, GIM estimate that in 1999 a one-point increase in the GIM index is associated with an 11.4 percentage point lower value for Tobin's Q. They also show that in the 1990s, firms with a low GIM index score outperform firms with a high GIM index score by an abnormal stock return of $8.5 \%$ per year which indicates that ATPs hurt shareholders. In their paper they give two possible explanations for the negative relation between their ATP index and stock returns. First they argue that weak shareholder rights caused agency problems and that as investors gained new information about the true costs that are associated with agency problems, share prices dropped to compensate for this new information. The second explanation they give is the classical missing variable explanation in corporate governance studies; some other variable correlated with the GIM index, rather than the GIM index itself, causes poorer performance. The GIM study has been followed by many investigations that aim to explain the way ATPs can impact shareholder wealth, and many have tested the robustness of results found by GIM.

Core et al., [3], one of the first to follow on to GIM, try to determine whether investors underestimated the agency costs associated with weak shareholder rights. They find that firms with high GIM index scores do not only have worse stock returns but also a worse operating performance than firms with low GIM index scores and conclude that weak shareholder rights are unlikely to cause lower abnormal stock returns. Instead, they argue that the difference in abnormal returns between high and low GIM index firms can be explained by a market model misspecification or something unique to the time period studied.

Bebchuk et al., [4] who also look at the influence of ATPs on firm value look at one specific ATP from GIM index. They focus strictly on staggered boards as a key anti-takeover provision and find that even a just a staggered board leads to significantly lower firm value. Bebchuk et al., [5], extend the GIM results further by looking at a smaller ATP index based on the six provisions that they argue to be most important from a legal point of view. They create a subset of six of the 24 GIM index which they call the "E index" and show that the strong negative relation between firm performance measures and GIM index is predominantly driven by the provisions in the $\mathrm{E}$ index. In their paper they show that an index consisting of staggered boards, limits to shareholder bylaw amendments, limits to shareholder charter amendments, supermajority requirements for mergers, poison pills, and golden parachutes have a stronger association with long-run stock returns and firm value than the GIM index does and that an index of the remaining 18 provisions has no significant relation to firm value.

By considering these results the first hypotheses is defined as:

H1: ATPs has negative relationship with the performance of the acquiring firm.

\section{Ownership Structure}

Prior studies focusing on the relationship between ownership and firm performance show that firm value increases with ownership of the largest shareholders [6]. Andre et al., [7] also in their paper report that companies owned by large block holders perform better than those owned by smaller investors.

The general opinion is that the presence of a large shareholder in widely held firms should have a positive impact on firm performance. Agency theory predicts that proper corporate governance mechanisms, such as ownership concentration, can reduce agency problems as stated by Jensen et al., [8], and Shleifer et al., [9]. It is suggested that the monitoring role of large shareholders is a good internal mechanism to reduce agency costs since these shareholders have greater incentives and resources to efficiently monitor the management and ensure value maximization. McConaughy et al., [6] also report positive relation between concentrated ownership and stock returns.

As concentrated ownership has its own specific costs and benefits, it is theoretically open which one dominates. Just as in the theoretical consideration, while some empirical researches support the positive relationship, other empirical researches suggests that concentrated ownership does not necessarily lead to better firm performance. Two recent meta-analyses $[10,11]$ find no substantive relationship between ownership structure and firm performance. It is noteworthy that the relationship is moderated by institutional environment: the relation is stronger in continental countries than in Anglo-Saxon countries, which would support the argument that ownership is more positively related to firm performance in countries with lower levels of investor protection.

There are countless studies that try to estimate the effects of institutional ownership on firm performance, but mixed results on this issue are reported. Although there is some evidence that institutional shareholders take an active role in corporate governance, there is no strong evidence suggesting positive effects of such shareholder activism on firm performance (for surveys, see [12-15]). Thomsen [16] also show empirically that firm performance first improves as ownership is more concentrated, but eventually declines in the largest European companies. It indicates that, at high levels of ownership concentration, the benefit of concentrated ownership is outweighed by the negative effects. Among the negative effects, the expropriation of small shareholders by large shareholders is noteworthy. LaPorta et al., [17] find that the main problem in large firms of 27 advanced countries may be the potential expropriation because controlling shareholders have control rights significantly in excess of cash flow rights via pyramid structure. Although there are some empirical studies show that the concentrated ownership impact on the performance of acquiring firm is negative but most of the empirical researches show positive relationship, therefore first Hypothesis is build up assuming the most prevailing results.

H2: The concentrated ownership is positively related to the performance of the acquiring firm. 
The purpose of this paper is to investigate the influence of new two main components of the corporate governance mechanism, namely anti-takeover provisions representing the external corporate governance mechanism and ownership concentration representing the internal corporate governance mechanism on the short and long term performance of overseas acquiring public Japanese firms.

\section{Data and Methodology}

\section{Sample construction}

Acquisitions sample is extracted from the transaction database of S\&P Capital IQ Platform. 222 observations are identified between the period January $1^{\text {st }}, 2004$ and December $31^{\text {st }} 2013$. Because two years post acquisitions financial data is needed to gauge the long term performance, the sample has to be stopped at the end of 2013. The sample is based on the following criteria:

- The acquisition is completed.

- The acquirer controls less than 50\% prior transaction and majority to $100 \%$ after the transaction.

- The deal value disclosed is more than $\$ 1$ million.

- The acquirer is a listed public company in the Nikkei225 index which has annual financial statement information available and stock return data (210 trading days prior to acquisition announcements).

- The transaction is cross-border.

\section{Research methodology}

This research principally employs quantitative method of data analysis in two steps, the first step entails the event study analysis on the announcement of cross-border merger and acquisitions to determine the cumulative abnormal returns (CARs) earned by the acquiring firm's shareholder. The second step is a series of liner multivariate regression analyses to achieve the purpose of the study which is to understand the influence of corporate governance namely ATPs and level of ownership concentration on the short and long term performance.

Representing short term performance metrics cumulative abnormal returns with two event windows were used, 2 days before and after announcement date denoted by (CAR2) and five days before and after announcement date denoted by (CAR5). For Long term performance measurement, accounting based metric is used which is return on assets (ROA).

The following three regression models were used to achieve the study purpose as following:

$$
\begin{aligned}
& C A R 2=\alpha+\beta 1 \text { ATPINDEX }+\beta 2 \text { TOP } 5 O W+\beta 3 F C F+\beta 4 \frac{M}{B}+ \\
& \beta 5 M A R K V A L+\beta 6 L E V G+\beta 7 \text { FIRMSIZE }+\beta 8 D E A L S I Z E+\beta 9 C B M A E X P+\varepsilon \\
& C A R 5=\alpha+\beta 1 \text { ATPINDEX }+\beta 2 \text { TOP } 5 O W+\beta 3 F C F+\beta 4 \frac{M}{B}+ \\
& \beta 5 M A R K V A L+\beta 6 L E V G+\beta 7 \text { FIRMSIZE }+\beta 8 D E A L S I Z E+\beta 9 C B M A E X P+\varepsilon \\
& \text { ROA }=\alpha+\beta 1 \text { ATPINDEX }+\beta 2 \text { TOP } 5 O W+\beta 3 F C F+\beta 4 \frac{M}{B}+ \\
& \beta 5 \text { MARKVAL }+\beta 6 L E V G+\beta 7 \text { FIRMSIZE }+\beta 8 D E A L S I Z E+\beta 9 C B M A E X P+\varepsilon
\end{aligned}
$$

\section{Variable construction}

Acquirer return: As stated earlier two event windows are used in this study CAR2 is the cumulative abnormal returns 2 days before and after announcement date which is denoted as date 0 , and CAR5 is the cumulative abnormal returns 5 days before and after announcement date. The Cumulative Abnormal Returns is formed by summing individual excess returns over time as in equation (4),

$$
\begin{aligned}
& \text { Where } \\
& C A R_{i, k, l}=\sum_{t=k}^{1} A R_{i t}
\end{aligned}
$$

Consistent with Masulis et al., [18] abnormal returns is estimated by using the market model. As shown in equation (5) the difference between the acquirer's stock return $\left(R_{i t}\right)$ and the expected stock return $\left(\alpha_{i}+\beta_{i} R_{i m}\right)$ is estimated with the acquirer's home country as market index $\left(R_{i m}\right)$.

$$
A R_{i t}=R_{i t}-\alpha_{i}-\beta_{i} R_{i m}
$$

The market model parameters are estimated over the 200-day period from event day from event day -210 to event day -11 .

Anti-Takeover provisions index: In this study, an index is formed based on ATP index created by Bebchuk [5]. The BCF index consists of six main components which have the most notable impact on firm performance: staggered boards, limits to shareholder bylaw amendments, limits to shareholder charter amendments, supermajority requirements for mergers, poison pills, and golden parachutes. Since Eikon Thomson Reuters Database has no information on limits to shareholder bylaw amendments and limits to shareholder charter amendments, they will be substituted by significant company transactions (M\&A) shareholders' approval component. Therefore, this study ATP index is based on five components which they are:

- Poison Pill.

- Staggered Boards Structure.

- Golden Parachute.

- Supermajority or qualified majority Vote Requirement.

- Significant Company Transactions (M\&A) shareholders' approval.

The ATP Index is based on scale from 0 to 5 with higher number representing stronger ATPs undertaken by the firm. Based on the five components, one point is assigned for limiting shareholder rights.

\section{Ownership structure}

This study looks at the top 5 owners of the firm based on the data available from Eikon Thomson Reuters database and the collective percentage of the top 5 owners is calculated and denoted as (TOP5OW) which indicate the concentration level of ownership. Ownership structure is considered as important internal mechanism of corporate governance and it is widely acknowledged to provide incentives for large shareholders to monitor management. As the ownership stake of large block holders increases, the block holders might have the greater incentive to increase firm performance and to monitor management than do dispersed shareholders. Furthermore, concerted actions by large shareholders are easier than by dispersed shareholders. Large shareholders have both an interest in getting their money back and the power to demand it. There are obvious benefits from concentrated ownership and generally is considered to have positive relationship with the performance of the firm.

\section{Control variables}

Other variables which are of less interest in this study and are 
controlled for are: Free Cash Flow which is denoted (FCF) and is extracted directly from Thomson Reuters Eikon database where is readily available for the quarter which the event fell in. Jensen's [19] free cash flow hypothesis argues that FCFs have a negative effect on bidder returns. As managers have more resources available it becomes easier to engage in empire building. It can however also be argued that higher FCFs are an indication of better firm performance. The performances could be correlated with higher quality managers and they tend to make better acquisition decisions Market to Book ratio $(\mathrm{M} / \mathrm{B})$ is calculated by dividing the Market value of equity over the book value of equity and this variable represent the growth opportunities. Market Value of Equity which is denoted (MARKVAL) and defined as the product of multiplying the number of outstanding shares on the quarter of the announcement by stock price at the $11^{\text {th }}$ trading day prior to announcement date.

Leverage which denoted (LEVG) is often seen as an important governance mechanism. A higher debt to equity ratio reduces futures FCFs due to interest obligations and it limits managerial discretion. Secondly, leverage increases the risk of bankruptcy it and provides management with an incentive to improve company performance and together with debt covenants managers risk losing control to creditors and might lose their jobs when the firms fall into default. Garvey et al., [20] even argue that leverage is related to a firm's takeover protection making it even more relevant as a control variable. Leverage is defined as total debt divided by a firm's market value of total assets. Firm Size which denoted (FIRMSIZE) is negatively correlated with the acquirer return as shown by Moeller et al., [21]. They find that on average larger acquirers pay higher premiums and make acquisitions that generate negative synergies and just as Roll they interpret the size effect as evidence supporting the managerial hubris hypothesis. Firm size is defined as the natural logarithm of the acquirer's total assets. Relative Deal Size is denoted (DEALSIZE) and is defined as total transaction value divided by market value of equity. Moeller et al., [21] find that acquirer announcement returns increase in relative deal size, but the reverse is true for a subsample of large acquirer in Moeller et al., [21]. As our focus is cross-border Merger \& Acquisitions, experience of acquiring firms in this type of transactions might be a factor which might also affect the performance and dummy variable is used as 1 indicate this is not first time for the firm to go for overseas transactions and 0 indicate first time cross-border acquirer. This variable denoted as (CBMAEXP).

\section{Results and Discussion}

\section{Descriptive and correlation statistics}

Prior to running the regressions, a descriptive statistics and a bivariate correlation analysis of the dependent and independent variables were conducted. Table 1 presents descriptive statistics for model variables which show that the mean and median cumulative abnormal returns which used as metrics for short term performance of the sample are negative and statistically not significant for both event windows, 2 days before and after event day and 5 days before and after event day. Long term performance indicator (ROA) is almost neutral as its mean and median value is 0.14 and 0.2 respectively indicating there is almost no notable change on the long-run performance.

The median value of the ATPs index is 1 which we decided to consider any firm with 2 or above value has strong ATPs in place while the firm with 1 value has weak ATPs and the firm with zero value has no ATPs.

\begin{tabular}{|l|c|c|c|c|c|}
\hline Variables & Mean & Median & Max & Min & St.d \\
\hline CAR2 & -0.00291 & -0.00019 & 0.097206 & -0.136815 & 0.039565 \\
\hline CAR5 & -0.00514 & -0.00457 & 0.148163 & -0.248355 & 0.054926 \\
\hline ROA & 0.145946 & 0.2 & 16.6 & -16.3 & 4.141 \\
\hline TOP5OW & 21.52365 & 19.08 & 72.31 & 9.62 & 10.92041 \\
\hline ATPINDEX & 1.459459 & 1 & 3 & 0 & 0.837836 \\
\hline FCF & 0.04961 & 0.035396 & 0.907314 & -3.299277 & 0.298085 \\
\hline LEVG & 0.947363 & 0.5225 & 11.181 & 0.0006 & 1.196889 \\
\hline M/B & 1.476149 & 1.199 & 12.284 & 0.167 & 1.111368 \\
\hline FIRMSIZE & 27.44371 & 27.494 & 29.709 & 24.731 & 0.873148 \\
\hline MARKVAL & 1.604839 & 1.09535 & 8.948652 & 0.053369 & 1.488103 \\
\hline DEALSIZE & 0.000892 & 0.0001 & 0.029 & 0.0000007 & 0.002871 \\
\hline CBMAEXP & 0.869369 & 1 & 1 & 0 & 0.337758 \\
\hline
\end{tabular}

Note: This table shows descriptive statistics of the dependent and independent variables. The dependent variables are (ROA) return on assets, (CAR5) cumulative abnormal returns for 5 days before and after announcement day and (CAR2) cumulative abnormal returns for 2 days before and after announcement day Independent variables are (ATPINDEX) the index for anti-takeover provisions. (DEALSIZE) the relative deal size. (FCF) the free cash flow, (MARKVAL) the market value of equity, (TOP5OW) the aggregate ownership percentage of top5 owners. (M/B) market to book ratio. (FIRMSIZE) the firm size and (LEVG) the leverage measured at announcement day.

Table 1: Descriptive statistics of the variables.

Table 2 shows the correlation matrix. Generally, there is not strong correlation found between variables as there is no value over 0.8 , the highest correlation value exists between CAR2 and CAR5 which is 0.687 but both variables are dependent variables and used in separate regression analyses. The next highest value registered in the correlation matrix is 0.664 between firm size and market value of equity as the former one represents the book size of the firm and the latter represents the actual and current market size and valuation of the firm and both of them used as control variables in the regression analyses which they are of less interest to our study.

\section{Regression analysis results}

Table 3 presents the results of the three regression analysis carried out in this study. The results show that the Anti-Takeover Provisions (ATPs) as external corporate governance mechanism has negative but statistically non-significant effect on the short term performance of the acquirer represented by the two indicators, cumulative abnormal returns with 2 days before and after the acquisitions day (CAR2) and 5 days before and after the acquisitions day (CAR5).

ATPs also has negative influence on the long term performance represented by (ROA) as shown on the regression C but statistically not significant. Generally speaking, ATPs have only minor negative influence on the short and long term performance of the overseas acquiring Japanese firms. This finding support weakly the hypothesis Hl: Anti-Takeover Provisions has negative relationship with the performance of the acquiring firms. Weak support because all the three regression analyses revealed statistically non-significant relationships between ATPs and short-term performance as well as long term performance. As this appear inconsistent with the strong negative association documented in Masulis et al., [18]. However, Core et al., [3] and Bebchuk et al., [22] argue that the adverse impact of ATPs has positively moderated in the period after 2001 . Since our sample includes more recent acquisitions than those used in Masulis et al., [18], our results are likely to reflect the diminishing association between ATPs and firm performance.

Statistically non-significant and very weak relationships $($ Beta $=$ 0 ) found also between the internal corporate governance component 
Citation: Faisal A (2016) Newly Adopted Corporate Governance Mechanism Impact on the Performance of Public Japanese Overseas Acquirers. J Glob Econ 4: 200. doi:10.4172/2375-4389.1000200

Page 5 of 6

\begin{tabular}{|c|c|c|c|c|c|c|c|c|c|c|c|}
\hline Variables & ATPINDEX & ROA & CAR5 & CAR2 & DEALSIZE & FCF & MARKVAL & TOP50W & M/B & FIRMSIZE & LEVG \\
\hline ATPINDEX & 1 & & & & & & & & & & \\
\hline ROA & -0.049 & 1 & & & & & & & & & \\
\hline CAR5 & -0.015 & -0.131 & 1 & & & & & & & & \\
\hline CAR2 & -0.006 & -0.091 & $0.687^{* *}$ & 1 & & & & & & & \\
\hline DEALSIZE & 0.062 & 0.053 & -0.022 & -0.079 & 1 & & & & & & \\
\hline FCF & -0.019 & -0.005 & 0.011 & 0.022 & 0.027 & 1 & & & & & \\
\hline MARKVAL & $-0.315^{\star *}$ & -0.033 & -0.048 & -0.05 & -0.122 & $0.235^{*+}$ & 1 & & & & \\
\hline TOP5OW & 0.103 & -0.059 & 0.007 & 0 & 0.034 & 0.131 & $0.146^{*}$ & 1 & & & \\
\hline$M / B$ & 0.087 & 0.041 & $-0.170^{*}$ & -0.075 & -0.028 & 0.06 & $0.371^{* *}$ & $0.189^{* *}$ & 1 & & \\
\hline FIRMSIZE & $-0.365^{\star \star}$ & -0.023 & 0.004 & -0.084 & $-0.148^{*}$ & $0.145^{\star}$ & $0.664^{* *}$ & $-0.163^{*}$ & $-0.155^{\star}$ & 1 & \\
\hline LEVG & $-0.138^{\star}$ & 0.061 & -0.064 & -0.06 & 0.064 & $-0.256^{* *}$ & -0.101 & $-0.279^{* *}$ & $-0.250^{\star *}$ & $0.162^{*}$ & 1 \\
\hline
\end{tabular}

Note: This table presents Pearson correlation statistics between the variables of the study (dependent and independent). The dependent variables are (ROA) return on assets, (CAR5) cumulative abnormal returns for 5 days before and after announcement day and (CAR2) cumulative abnormal returns for 2 days before and after announcement day. Independent variables are (ATPINDEX) the index for anti-takeover provisions. (DEALSIZE) the relative deal size. (FCF) the free cash flow, (MARKVAL) the market value of equity, (TOP5OW) the aggregate ownership percentage of top5 owners. (M/B) market to book ratio. (FIRMSIZE) the firm size and (LEVG) the leverage measured at announcement day.

** and * indicate significance at the 5 and 10 percent levels respectively.

Table 2: Correlation statistics.

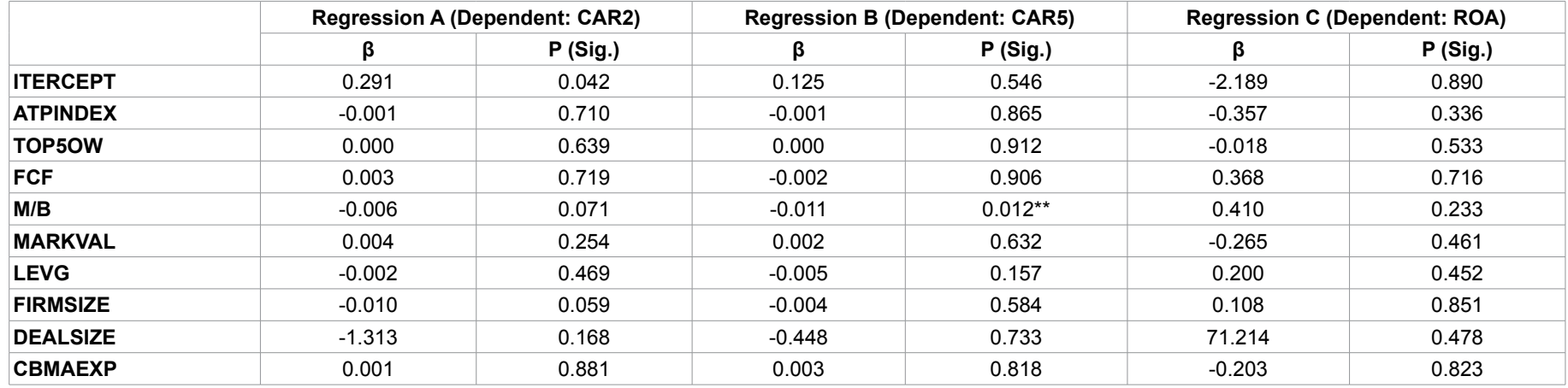

Note: This table presents results of the three regression analyses: regression A with (CAR2) the cumulative abnormal returns for 2 days before and after announcement date as dependent variable, regression $B$ with (CAR5) the cumulative abnormal returns for 5 days before and after announcement date as dependent variable and regression $C$ with (ROA) return of assets as dependent variable. Independent variables of interest are (ATPINDEX) the index for anti-takeover provisions and (TOP5OW) the aggregate ownership percentage of top5 owners. Other independent variables are (DEALSIZE) the relative deal size. (FCF) the free cash flow, (MARKVAL) the market value of equity, $(\mathrm{M} / \mathrm{B})$ market to book ratio, (FIRMSIZE) the firm size and (LEVG) the leverage measured at announcement day.

** indicate significance at the 5 percent level.

Table 3: Regression results.

represented through ownership concentrations (TOP5OW) and short term performance of acquiring Japanese firms represented by CAR2 and CAR5. The relationship become negative with long term performance indicator (ROA) and statistically insignificant.

Therefore, this finding of insignificant relationship between the ownership concentration and both short and long term performance of the Japanese public acquiring firms does not support our second hypothesis $\mathrm{H} 2$ : The concentrated ownership is positively related to the performance of the acquiring firm [23-25].

\section{Conclusion}

Whether to keep takeover defenses or dismantle it is becoming a major issue at many Japanese public companies as new corporate governance code implemented by the Tokyo Stock Exchange has prompted many to ditch anti-takeover Provisions (ATPs) and as the code requires companies with takeover defenses to fully explain their reasons to investors. Behind the trend is strong criticism from investors who see takeover defenses as nothing more than a self-serving tool for management. This research finding reveals that ATPs has almost neutral influence on the short and long term performance of overseas acquiring public Japanese firms in the last decade which does not really support the managerial entrenchment hypothesis and cannot find strong evidence for the self-dealing as there is no real shareholder value destruction caused by the cross-border merger and acquisitions and performance almost did not change in the short and long run. Therefore, the investors should have less worries about ATPs in Japan as it seems that they are not as effective as in other developed markets such as USA.

As it was revealed by this study, the relationship between the ownership concentration represented by the cumulative percentage of the top 5 owners and the short as well as long term performance are almost not existing which implies that institutional and foreign ownership system which replaced the old bank centered system in the last decade still have not worked to enhance the shareholder value.

\section{References}

1. DeAngelo H, Rice EM (1983) Anti-takeover charter amendments and stockholder wealth. Journal of Financial Economics 11: 329-360.

2. Gompers PA, Ishii JL, Metrick A (2003) Corporate governance and equity price. Quarterly Journal of Economics 118: 107-155.

3. Core JE, Guay WR, Rusticus TO (2006) Does weak governance cause weak stock returns? An examination of firm operating performance and investors' expectations. Journal of Finance 61: 655-687. 
Citation: Faisal A (2016) Newly Adopted Corporate Governance Mechanism Impact on the Performance of Public Japanese Overseas Acquirers. J Glob Econ 4: 200. doi:10.4172/2375-4389.1000200

Page 6 of 6

4. Bebchuk LA, Cohen A (2005) The costs of entrenched boards. Journal of Financial Economics 78: 409-433.

5. Bebchuk LA, Cohen A, Ferrell A (2009) What matters in corporate governance? Review of Financial Studies 22: 783-827.

6. McConaughy DL, Walker MC, Henderson GV, Mishra CS (1998) Founding family controlled firms: Efficiency and value. Review of Financial Economics 7: 1-19.

7. Andr'e P, Kooli M, L'Her JF (2004 ) The long-run performance of mergers and acquisitions: Evidence from the Canadian stock market. Financial Management 33: $27-43$.

8. Jensen MC, Meckling WH (1976) Theory of the firm: Managerial behavior, agency costs and ownership structure. Journal of Financial Economics 3: 305360 .

9. Schleifer A, Vishny RW (1986) Large shareholders and corporate control Journal of Political Economy 94: 461-489.

10. Dalton D, Daily C, Certo T, Roengpitya R (2003) Meta-analyses of financial performance and equity: Fusion or confusion? Academy of Management Journal 46: 13-26.

11. Sanchez-Ballesta JP, Garcia-Meca E (2007) A meta-analytic vision of the effect of ownership structure on firm performance. Corporate Governance 15: 879-893.

12. Black BS (1998) Shareholder activism and corporate governance in the U.S The New Palgrave Dictionary of Economics and the Law 3: 459-465.

13. Gillan SL, Starks LT (1998) A survey of shareholder activism: motivation and empirical evidence. Contemporary Finance Digest 2: 10-34.

14. Romano $\mathrm{R}$ (2001) Less is more: making institutional investor activism a valuable mechanism of corporate governance. Yale Journal on Regulation 18: 174-251.

15. http://group27.narod.ru/ucheba/files/tasis/Documents/English/3/3-7.pdf

16. Thomsen S, Pedersen T (2000) Ownership structure and economic performance in the largest European companies. Strategic Management Journal 21: 689-705

17. La Porta R, Lopez F, Shleifer A, Vishny RW (1999) Corporate ownership around the world. Journal of Finance 54: 471517.

18. Masulis RW, Wang C, Xie F (2007) Corporate governance and acquirer returns Journal of Finance 62: 1851-1889.

19. Jensen MC (1986) Agency costs of free cash flow, corporate finance, and takeovers. American Economic Review 76: 323-329.

20. Garvey GT, Hanka G (1999) Capital structure and corporate control: The effect of state antitakeover laws on firm leverage. Journal of Finance 54: 519-546.

21. Moeller SB, Schlingemann FP, Stulz R (2004) Firm size and the gains from acquisitions. Journal of Financial Economics 73: 201-228.

22. Bebchuk LA, Cohen A, Wang CY (2013) Learning and the disappearing association between governance and returns. Journal of Financial Economics 108: 323-348.

23. Anderson RC Reeb DM (2003) Founding-family ownership and firm performance: Evidence from the S\&P 500. Journal of Finance 58: 1301-1329.

24. Claessens S, Djankov S, Fan JPH, Lang LHP (2002) Disentangling the Incentive and Entrenchment Effects of Large Shareholdings. Journal of Finance 57: 2741-2772.

25. La Porta R, Lopez-de-Silanes F, Shleifer A, Vishny RW (2002) Investor protection and corporate valuation. The Journal of Finance 57: 1147-1170. 